The Driving Forces of Human Nature. By Dom Thomas Verner Moore, O.S.B., Ph.D., M.D. Wm. Heinemann Medical Books. 35s.

This book by a Roman Catholic Professor of psychiatry and psychology is written in the usual forceful way expected of Dom Thomas Moore. Unlike the book Christianity after Freud, also reviewed in these columns, it is much more dogmatic and pre-supposes an unquestioning acceptance of the principles of the Christian faith. The figures dealing with mental ill-health in selected populations, and relating them to the average in the community, are particularly revealing.

This may be the last book we shall have from the vigorous pen of Dom Thomas, as it is understood that he has now entered a Trapist monastery.

\section{A.T.}

Mental Readjustment. By Sidonie Reiss. With a prefatory note by Alexandra Adler, M.D. Translated by Bernard Miall. London: George Allen \& Unwin, Ltd. 167 pp. 10s. 6d. net.

The interpretation of a prophet to a succeeding generation presents problems which are not entirely solved in this brief attempt to convey to parents and teachers of small children, to social workers and related professions, the essence of the School of Individual Psychology founded by Alfred Adler.

Faced with the choice of either explaining at the beginning that the book is a presentation of Adler's work, and then allowing the text to speak for itself, or else continuing throughout to give credit to the Master as each point is made, Miss Reiss chooses the latter, perhaps unwisely. The result is not only a hint of adulation, but also that Adler is credited with a great many "discoveries ", many of which are mere commonplaces and some are part of traditional wisdom. It is correspondingly difficult to find out from this book exactly what Adler's contribution has been to psychological thought.

Miss Reiss is clearly happier when presenting case material than explaining theory; and the obscurities of the first part-perhaps the translator was uncomfortable too-are not met with later. The case histories are interesting, but it is a comparatively simple world which is described. The bark of childhood, sturdy though it is, sails perilously between the Scylla of parental " cossetting" and the Charybdis of parental severity, laden with organ inferiority and steering, not by right and wrong which have been abolished, but by correct behaviour and error. Or perhaps the reviewer in search of a striking metaphor is guilty of over-simplification too.

The recent spate of books explaining psychology to parents, teachers and social workers has left its mark in a certain degree of sophistication, and perhaps Miss Reiss would have been better advised to take her readers more into her confidence. Many of these readers will wish to know in greater detail the relationship between cause and effect in children's psychological problems, and will not be content any longer with a description of effect and a bare statement of cause. They will want to know in greater detail how these mechanisms work, what governs the final path of a neurotic reaction and what is the evidence of this alleged organ "sensitivity" to trouble.

Perhaps the most surprising feature of the book is a remark in a prefatory note by Dr. Alexandra Adler that " the author avoids sweeping generalizations ". On the contrary, the theoretical section of this book is no deeper than the level of generalizations, and the author should consider attempting to satisfy the hunger of this section of the reading public for a more serious exposition of her subject.

K.S.

Probation and Re-education. By Elizabeth $\mathrm{R}$. Glover, M.A., late Deputy Principal Probation Officer for London. Routledge \& Kegan Paul. 12s. 6d.

"Probation Officers", a learned Magistrate told the 1936 Committee on Social Services in Summary Courts, "suffer from too much illconsidered praise and too little well-considered criticism." Since then, a dozen books by magistrates and lawyers have lauded the probation officers .... and left us ignorant of what they do and how they do it. Miss Glover's book tells us what and how. The style of the book, with its interest directed always to the probationer rather

\title{
AN APOLOGY
}

We regret very much an error in our review on page 24 of the August issue (Vol. IX, No. 1) entitled "The Mental Health Aspect of Public Health". This stated that the chapter under this title by Dr. Doris Odlum in Modern Trends in Public Health had been published as a separate pamphlet. In fact, this is not so. We apologize sincerely to the publishers for any inconvenience our error caused them. Unfortunately we took the reprint sent to us by Dr. Odlum as a separate pamphlet.

The whole book is published by Butterworth \& Co. Ltd. (50s.; postage 1s. 6d.), and although only Dr. Odlum's chapter was reviewed as being of special interest to readers of this journal, the whole publication is a most excellent one. It is edited by Dr. Arthur Massey, C.B.E., with a foreword by Sir Wilson Jameson, K.C.B., M.D., F.R.C.P., and among other chapters which it contains are: The idea of a Family Health Club, Social Medicine as an academic discipline, General Practice and its contribution to Preventive Medicine, School Health Service, Health Centres in their relation to Social Medicine and Public Health, Child Health and the Universities, Day Nurseries, Occupational Health, and Health Education. 
than to the author, is itself an object lesson in social work.

Chapter I should be read by Juvenile Court magistrates and clerks. The next six chapters constitute a manual of practice for probation officers, and the rest of the book discusses the probationer's personal relationships.

Miss Glover's approach is summed up by her welcome to psychiatry in the Courts, which leads us "from the purely legal and moral approach to the scientific and curative one. It has taught us that all conduct, good or bad, has a reason; and one must find the reason before one can hope to correct it". Yet she retains the moralistic pre-occupations of the ardent social worker and has no use for treatment which deters from further offence without altering character. One can accept the aspirations implied in the chapter on Probation as Treatment while admitting what Miss Glover does not admit: that most probationers resolve to keep in future within the law, not because of fundamental emotional changes or altered moral standards, but because they have been brought to intellectual acceptance of the common belief that petty crime does not pay. Society pays heavily for the locksmith, the ticket collector, the policeman and the hanging judge; who keep theft, swindling and violence within tolerable bounds. Probation officers need not deny that they are part of this machinery of prevention and deterrence.

The author's ideal probation officer is intensely thoughtful as well as active, and uses no rule-ofthumb, routine approaches to situations which are superficially alike. The standards she sets imply case loads of forty to fifty (with no extraneous duties) - the case loads advocated in Appendix $I$. Even then, it is shown that in twelve months' probation the time actually spent with the officer is about ten hours. It is in her emphasis on personal relationships and contacts, as opposed to the mere mechanics of escorting, advising and job-finding, that Miss Glover's practical exposition differs from the external observations of other writers. "The officer's sharing each disappointment may be of more value than actual success" (p. 120). Some magistrates expect that a process of "settling down" will follow their brief and barely understood admonition. The probation officer knows that people, unlike fermenting liquors, do not attain maturity through stagnation.

It is a sign of the times that the references to local authority functions in juvenile courts, and to their welfare services, are already out of date. Miss Glover pays tribute to an interesting list of fifty books, some unexpected.

K.H.B.

\section{Film Reviews}

\section{The Search. (Featuring Montgomery Clift and Ivan Jandl.)}

It may be felt that the subject of the orphaned, stateless children of Europe needs no underlining or highlights, but the devastation left after war is a tragedy upon which we should necessarily dwell.

As portrayed in The Search, the story of the little Czech boy who like many other children is separated from his mother while in a concentration camp, then branded by the Nazis and later taken to an U.N.R.R.A. centre, is tremendously moving. The ensuing scenes of the terrified child running away from what he thinks is a death van, the mother's search for her lost child, the boy's growing confidence in the American soldier, are all unforgettable. Unfortunately, there is never any beauty on which the eye can rest. We have two scenes by the river, but each time it is only the background for sad action or theme. Some shots of the children are beautiful, but it is a thin beauty. Their strained anxious faces peer out on ruins.

The acting of the amateurs and professionals is good. The latter are well represented by Montgomery Clift and Aline MacMahan. But sometimes I felt they were showing us a little too expertly how to be kind to children, and within these limits they could both have improved their performance by pitching their voices on a gentler note.
The skilful simplicity of Fred Zinneman's direction seems to stamp the whole film as sincere and humane. But it is well to keep in mind the criticism which asked if this subject would have been better treated as a documentary? As it is, The Search throws out many emotional threads which interweave closely with our own infantile associations and frustrations. Hence we wonder if a straightforward statement of facts would be more helpful towards an adult assessment of things as they were.

\section{H.U.B.}

\section{Obsession. (Featuring Robert Newton, Naunton Wayne and Sally Gray.) $98 \mathrm{~min}$.}

In the recent Bulletin of the World Federation for Mental Health, Professor John M. Murray has written of "the acceptance of psychiatry as a rightful member at the family table of medicine". But the family must be an exclusive one or one, at any rate, that does not welcome visitors from the cinema world. For on the screen the psychiatrist is not yet a rightful member of any family table.

In the film Obsession, this un-family man is a husband who is bitterly jealous and resentful of his wife's frequent flirtations. So he decides to seize the next man, keep him in an underground cellar until the hue and cry raised by his disappearance has died down and then kill him, dissolving the 